\title{
Diagnosis and Treatment of Transforaminal Epidural Steroid Injection in Lumbar Spinal Stenosis
}

\author{
Ismail Yuce, ${ }^{1}$ - Okan Kahyaoglu, ${ }^{2}$ (i) Muzeyyen Ataseven, ${ }^{3}$ () Halit Cavusoglu, ${ }^{1}$ () Yunus Aydin ${ }^{2}$ \\ 'Vocational School of Health Services, Acıbadem Mehmet Ali Aydınlar University, Istanbul, Turkey \\ ${ }^{2}$ Fulya Hospital, Acıbadem Healthcare Group, Istanbul, Turkey \\ ${ }^{3}$ Vocational School of Health Services, İstanbul Medipol University, Istanbul, Turkey
}

\begin{abstract}
Objectives: Transforaminal epidural steroid injection reduces the low back-leg pain and enables daily activities of the patients. In this study, we aim to evaluate the treatment of transforaminal epidural steroid injection for lumbar spinal stenosis, which was mainly performed for lumbar disc herniation and share our diagnostic experience for lumbar spinal stenosis which is treated surgically.

Methods: In our study, 37 patients were included who were treated by transforaminal epidural steroid injection for Grade B lumbar spinal stenosis in our clinic between June-2014 and June-2018. We evaluated the patients at the second weeks, third/sixth months and one year after the treatment by Oswestry-Disability-Index and Visual-Analogue-Scale and followed up for surgical treatment after one year.

Results: The mean low back and leg pain Visual Analogue Scale was $5.1 \pm 0.3$ before the transforaminal epidural steroid injection procedure, and it was $2.7 \pm 0.1$ after two weeks. It was $2.8 \pm 0.2,3.1 \pm 0.1$ at three and six months after procedure, respectively. The improvement of low back-leg pain mean Visual-Analogue-Scale is statistically significant at two weeks, three and six months after transforaminal epidural steroid injection procedure, respectively. The mean Oswestry-Disability-Index was $29.6 \pm 0.4$ before the transforaminal epidural steroid injection procedure, and it was $14.1 \pm 0.3$ after two weeks. It was $15.3 \pm 0.5,24.4 \pm 0.2$ at three and six months after procedure, respectively. The improvement of Oswestry-Disability-Index is statistically significant at two weeks, three-six months.

Conclusion: The transforaminal epidural steroid injection is safe procedure for non-surgical treatment of lumbar spinal stenosis and this procedure may be preferred support to the indication of the surgical treatment of level of lumbar spinal stenosis.

Keywords: Non-surgical treatment; lumbar spinal stenosis; transforaminal epidural steroid injection.

Please cite this article as "Yuce I, Kahyaoglu O, Ataseven M, Cavusoglu H, Aydin Y. Diagnosis and Treatment of Transforaminal Epidural Steroid Injection in Lumbar Spinal Stenosis. Med Bull Sisli Etfal Hosp 2020;54(3):327-332".
\end{abstract}

$\mathrm{O}$ ne of the degenerative pathologies of the lumbar spine is lumbar spinal stenosis (LSS) and it is a common cause of radicular pain. ${ }^{[1-3]}$ The pathology appears as foramen, lateral recess and central stenosis on lumbar magnetic resonance image (MRI). The morphologic classification of LSS on lumbar MRI has been described by measuring the dural sac cross-sectional surface area in the literature. ${ }^{[4]}$ The severe and extreme stenosis is treated with surgery generally and minor or moderate stenosis is treated conservatively. The complaints of patients are low back pain or bilaterally leg pain in a few patients. According to our clinical experience, especially in the foramen and lateral recess ste-

Address for correspondence: Ismail Yuce, MD. Acibadem Mehmet Ali Aydinlar Universitesi, Saglik Hizmetleri Meslek Yuksekokulu, Istanbul, Turkey Phone: +90505 3760182 E-mail: dr.ismailyuce@gmail.com

Submitted Date: December 31, 2019 Accepted Date: April 28, 2020 Available Online Date: August 24, 2020

${ }^{\circ}$ Copyright 2020 by The Medical Bulletin of Sisli Etfal Hospital - Available online at www.sislietfaltip.org

OPEN ACCESS This is an open access article under the CC BY-NC license (http://creativecommons.org/licenses/by-nc/4.0/) 
nosis, complaints are more prominent. Transforaminal epidural steroid injection (TFESI) reduces the low back or leg pain and enables daily activities in patients who have been foramen or lateral recess stenosis of the lumbar spine on lumbar MRI. ${ }^{[5-8]}$ This study aims to evaluate the treatment of the TFESI for LSS, which was mainly performed for lumbar disc herniation and share our diagnostic experience for LSS, which was treated surgically.

\section{Methods}

This retrospective study was approved by the Ethical Committee of İstanbul Medipol University. Approval No: $1115 / 11122019$. Thirty-seven patients were included in our study who were treated by TFESI in our clinic between June 2014 and June 2018. Inclusion criteria: Refractory to adequate conservative treatment before three months TFESI, Grade B LSS on lumbar MRI (Fig. 1), low back and bilaterally leg pain complain, were performed TFESI on one level bilaterally. The patients who had neurological claudication or deficits were excluded from this study. The patients were
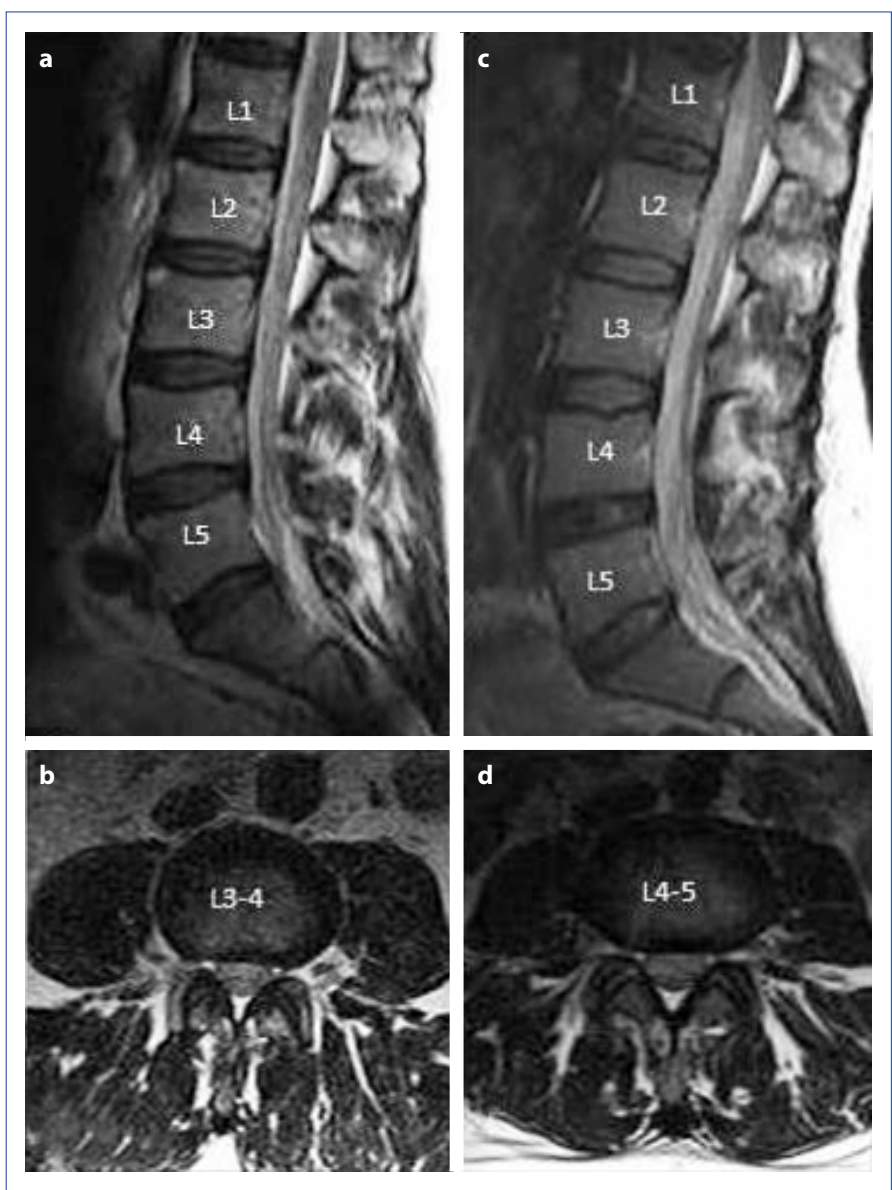

Figure 1. A,B Lumbar Magnetic Resonance Image of Grade B L3-4 spinal stenosis, $C, D$ Lumbar Magnetic Resonance Image of the Grade B L4-5 spinal stenosis, A and C Sagittal images, B and D axial images. suggested exercises for three months after TFESI. We evaluated the patients at two weeks, three and 6 six months, one year after treatment using Oswestry Disability Index (ODI) and Visual Analogue Scale (VAS). All patients were admitted to the neurosurgery department with an ODI questionnaire and VAS conducted by the medical secretary. Patients were asked questions via face-to-face assessment, or questions were addressed to family members if the patients had communication problems owing to regional dialect. Additionally, we determined exercise-free compatibility of our patients after three months of TFESI treatment.

\section{Surgical Procedures}

TFESI was performed in the operation theatre equipped with $C$ army scopy while the patients were prone to position in our clinic. The 21-gauge spinal needle was advanced towards the involved neural foramen under scopy after sterile preparation and local anesthesia (Fig. 2). The one milliliter of contrast material (iohexol, $300 \mathrm{mg}$ iodine per milliliter) was injected to confirm the epidural area to avoid intradural or intravascular infiltration by anteroposterior and lateral X-ray imaging. The 0.5 -milliliter bupivacaine $\mathrm{HCl}$ and 1-milliliter methylprednisolone acetate are injected into intervertebral foramen. The procedure is finished after the exam of the patient.

\section{Statistical Analysis}

The data obtained from the cases were recorded using Microsoft Excel-2013. SPSS 21 (Statistical Package for Social Sciences) for Windows Software was used for the evaluation of the findings (mean and standard deviation). Distribution of the data was analyzed using paired-independent sample, one way ANOVA tests. Statistical significance was set at a probability value of $<0.05$ ( $\mathrm{Cl}$ : Confidence Interval 95\%).

\section{Results}

The 37 patients ( 21 were men, 16 were women) who underwent TFESI procedure for Grade B LSS were evaluated in our study. Twenty-eight of all patients did not have sus-

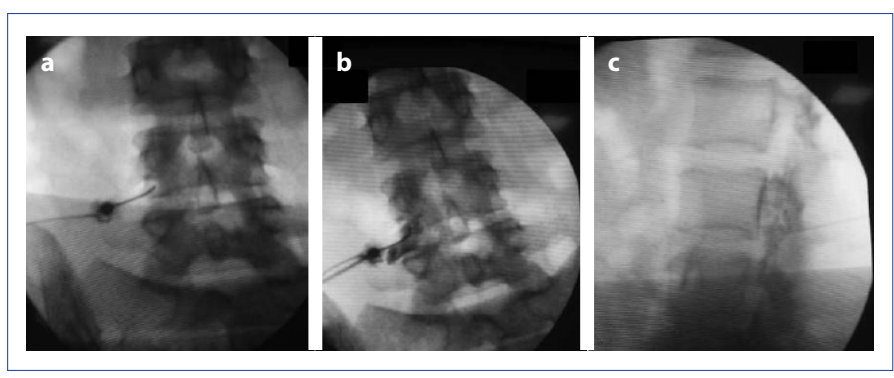

Figure 2. X-ray graphy of L4-5 transforaminal injection/A, B Anterior-posterior images, C Lateral image. 
tainable clinical improvement by conservative treatment (medical and exercises/three months) before TFESI. Five of the nine patients refused to exercises and four patients refused to medical treatment and 19 of 28 patients who were not satisfied after conservative treatment were not apply medical treatment regularly before the procedure. 13 of 37 patients were treated L3-4 and 24 patients were treated L4-5 level of lumbar spine bilaterally (Table 1).

The mean low back and leg pain VAS was $5.1 \pm 0.3$ before the TFESI procedure and it was $2.7 \pm 0.1$ after two weeks. It was $2.8 \pm 0.2,3.1 \pm 0.1$ at three and six months after procedure, respectively. The diversity of pre-procedure VAS between L3-4 and L4-5 was not statistically significant ( $p>0.05$ ). The reduction of low back and leg pain mean VAS was statistically significant at two weeks, three and six months after TFESI procedure, respectively $(p<0.05)$ (Table 1$)$. In this study, 28 of $37(76 \%)$ patient's VAS decreased to $50 \%$ at six months (Table 2).

Table 1. Demographics of the patients

\begin{tabular}{|c|c|c|c|c|}
\hline Parameters & & $\mathbf{n}$ & $\%$ & $\mathbf{p}$ \\
\hline Mean age & $42.6 \pm 5.4$ & & & \\
\hline \multicolumn{5}{|l|}{ Gender } \\
\hline Male & & 21 & 56.8 & \\
\hline Female & & 16 & 43.2 & \\
\hline \multicolumn{5}{|l|}{ Level } \\
\hline L3-4 & & 13 & 35.1 & \\
\hline L4-5 & & 24 & 64.9 & \\
\hline \multicolumn{5}{|l|}{ VAS } \\
\hline Pre-procedure & $5.1 \pm 0.3$ & & & \\
\hline After 2 weeks & $2.7 \pm 0.1$ & & & \\
\hline After 3 months & $2.8 \pm 0.2$ & & & \\
\hline After 6 months & $3.1 \pm 0.1$ & & & \\
\hline After 1 year & $4.6 \pm 0.2$ & & & \\
\hline $\begin{array}{l}\text { Differences of pre- } \\
\text { procedure/2 weeks }\end{array}$ & $2.4 \pm 0.2$ & & & 0.01 \\
\hline $\begin{array}{l}\text { Differences of } 2 \text { week/ } \\
6 \text { months }\end{array}$ & $0.4 \pm 0.1$ & & & 0.01 \\
\hline $\begin{array}{l}\text { Differences of } 6 \text { months/ } \\
1 \text { year }\end{array}$ & $1.5 \pm 0.2$ & & & 0.01 \\
\hline \multicolumn{5}{|l|}{ ODI } \\
\hline Pre-procedure & $29.6 \pm 0.4$ & & & \\
\hline After 2 weeks & $14.1 \pm 0.3$ & & & \\
\hline After 3 months & $15.3 \pm 0.5$ & & & \\
\hline After 6 months & $21.7 \pm 0.4$ & & & \\
\hline After 1 year & $24.4 \pm 0.2$ & & & \\
\hline $\begin{array}{l}\text { Differences of pre-procedure/ } \\
2 \text { weeks }\end{array}$ & $15.5 \pm 0.2$ & & & 0.01 \\
\hline Differences of 2 weeks/ 6 months & $7.6 \pm 0.3$ & & & 0.01 \\
\hline Differences of 6 months $/ 1$ year & $2.7 \pm 0.1$ & & & 0.01 \\
\hline
\end{tabular}

Four of 37 patients who were not determined at one year were consulted by phone and three of them refused to control and one of four patients was operated in other clinic for LSS. 33 of 37 patients were determined after one year and their mean VAS was $4,6 \pm 0.2$. The worsening of VAS between six months and one year was statistically significant $(p<0.05)$ (Table 1).

Seven of 33 patients who were determined at one year were treated surgically by bilateral decompression via a unilateral approach for LSS in our clinic. Five patients who were refusing to exercise before the TFESI procedure could have an exercise and have sustainable clinical improvement. The TFESI procedure was performed twice to two patients who had higher VAS at six months than two weeks after the procedure.

The mean ODI was $29.6 \pm 0.4$ before TFESI procedure, and it was $14.1 \pm 0.3$ after two weeks. It was $15.3 \pm 0.5,24.4 \pm 0.2$ at three and six months after procedure, respectively. The diversity of pre-procedure ODI between L3-4 and L4-5 was not statistically significant ( $p>0.05)$. The improvement of mean ODI is statistically significant at two weeks, three and six months after TFESI procedure, respectively $(p<0.05)($ Table 1). 24 of 37 (65\%) patient's ODI were improved by $50 \%$ at six months (Table 2).

In this study, 10 of the 33 patients who were determined at one year after procedure have worse ODI score and seven of 10 patients were treated surgically by bilaterally decompression via a unilateral approach for LSS. This rate was statistically significant for the diagnostic approach for surgical treatment of Grade B lumbar spinal stenosis $(p<0.05)$.

We evaluated complications at one patient in our study. It was a weakness (left leg) after the early period of the TFESI procedure. After three days with rest, the weakness was not determined. There was no other complaint in this patient. The other complications were not determined in our study.

\section{Discussion}

TFESI procedure is widely used in Neurosurgery, Orthopedy, Physical Therapy and Rehabilitation Clinics for the treatment of radiculopathy commonly caused by a lumbar disc herniation. The coverage guidelines deem surgical treatment for lumbar disc herniation or stenosis unnecessary unless physical therapy, medical therapy, such as nonsteroidal anti- inflammatory drugs or TFESI. ${ }^{[9]}$ The non-surgical treatment of LSS by TFESI was performed in studies and its results were evaluated in the literature (Table 2). ${ }^{[10-14]}$

ODI criteria and VAS, which are widely used in the literature, were used to evaluate the neurological status and pain complaints of our patients. ${ }^{[10,13]}$ 
Table 2. The evidence on epidural steroid injection for lumbar spinal stenosis from the literature

\begin{tabular}{|c|c|c|c|c|c|}
\hline Study/Year & $\begin{array}{l}\text { Lumbar } \\
\text { pathology }\end{array}$ & Sample size & $\begin{array}{l}\text { Follow-up } \\
\text { (weak) }\end{array}$ & $\begin{array}{l}\text { Outcome } \\
\text { measures }\end{array}$ & Main Findings \\
\hline Kim HJ. et al..[13]/2014 & $\begin{array}{l}\text { Lumbar spinal } \\
\text { stenosis }\end{array}$ & 77 & 8 & $\begin{array}{l}\text { Visual Analogue } \\
\text { Scale and } \\
\text { Oswestry } \\
\text { Disability Index }\end{array}$ & $\begin{array}{l}\text { Improving pain and disability } \\
\text { Visual Analogue Scale back pain 99\% } \\
\text { Visual Analogue Scale leg pain 100\% } \\
\text { Oswestry Disability Index 100\% }\end{array}$ \\
\hline Park Y. et al. ${ }^{[10] / 2015}$ & $\begin{array}{l}\text { Lumbar foraminal } \\
\text { stenosis }\end{array}$ & 45 & 12 & $\begin{array}{l}\text { Verbal Numeric } \\
\text { Pain Scale and } \\
\text { Oswestry } \\
\text { Disability Index }\end{array}$ & $\begin{array}{l}>50 \% \text { improvement in Verbal Numeric } \\
\text { Pain Scale } \\
>40 \% \text { improvement in Oswestry } \\
\text { Disability Index } \\
\text { Group percutaneous adhesiolysis } 73.3 \% \\
\text { Group fluoroscopy-guided transforaminal } \\
\text { epidural steroid injection } 43.3 \%\end{array}$ \\
\hline $\begin{array}{l}\text { Davis N, Hourigan P, } \\
\text { Clarke A. }{ }^{[14]} / 2016\end{array}$ & $\begin{array}{l}\text { Lumbar spinal } \\
\text { stenosis }\end{array}$ & 68 & 96 & $\begin{array}{l}\text { Avoidance of } \\
\text { decompressive } \\
\text { surgery }\end{array}$ & $\begin{array}{l}\text { Crossed over to surgery } 22(32 \%) \\
\text { No symptoms } \% 44\end{array}$ \\
\hline $\begin{array}{l}\text { Farooque M, Salzman MM, } \\
\text { Ye Z. }{ }^{[12]} / 2017\end{array}$ & $\begin{array}{l}\text { Lumbar spinal } \\
\text { stenosis }\end{array}$ & 28 & 24 & Pain score & $\begin{array}{l}50 \% \text { Reduction in Pain Score at } 1 \text { month 30\% } \\
50 \% \text { Reduction in Pain Score at } 3 \text { month 53\% } \\
50 \% \text { Reduction in Pain Score at } 3 \text { month 44\% }\end{array}$ \\
\hline Chang MC, Lee DG. $.^{[11]} / 2018$ & $\begin{array}{l}\text { Lumbar foraminal } \\
\text { stenosis }\end{array}$ & 60 & 12 & $\begin{array}{l}\text { Numeric rating } \\
\text { scale }\end{array}$ & $\begin{array}{l}\text { Three months after treatment, } 27 \text { patients } \\
(87.1 \%) \text { in group } A \text { and } 11 \text { patients }(42.3 \%) \text { in } \\
\text { group B reported successful pain relief (pain } \\
\text { relief of } \geq 50 \%) \text {. }\end{array}$ \\
\hline Present Study & $\begin{array}{l}\text { Grade B lumbar } \\
\text { spinal stenosis }\end{array}$ & 37 & 48 & $\begin{array}{l}\text { Visual Analogue } \\
\text { Scale and Oswestry } \\
\text { Disability Index }\end{array}$ & $\begin{array}{l}28 \text { ( } 76 \% \text { ) } 50 \% \text { Reduction in Visual Analogue } \\
\text { Scale at } 6 \text { months } \\
24 \text { (65\%) } 50 \% \text { Improvement in Oswestry } \\
\text { Disability Index at } 6 \text { months } \\
7 / 33 \text { (21\%) at } 1 \text { year surgical treatment for } \\
\text { Grade B lumbar spinal stenosis (diagnostic } \\
\text { approach) }\end{array}$ \\
\hline
\end{tabular}

The morphologic classification of LSS on lumbar MRI was defined by Schizas C. et al. ${ }^{[4]}$ We evaluated our patient's lumbar MRI imaging by this classification and TFESI procedures were performed grade B stenosis in our study.

The safely method of TFESI procedure has been described in the literature. The aim of the procedure is to provide clinical improvement by suppressing the inflammation with steroid efficacy around the dorsal root that constitutes the complaint. The patients with minor or moderate stenosis have nerve root impingement in lateral recess or lumbar foramen. The stenosis may lead to continuous mechanical stimulation of the nerves and repeated occurrence of inflammation (interleukin-1, tumor necrosis factor and phospholipase A2) in the nerve root when the condition persists. TFESI, which includes steroid and local anesthetics, such as the present study provides inhibition of prostaglandin synthesis, stabilization of cellular membranes, and suppression of immune responses, increases in neuronal blood flow, and washing out inflammatory mediators (such as interleukin-1, tumor necrosis factor and phospholipase A2). ${ }^{[15-19]}$

TFESI procedure is a more effective treatment to lumbar disc herniation or stenosis for patient whose age is $<50$ years than elderly patients. ${ }^{[20]}$ The mean age of our patients was $42.6 \pm 5.4$ in present study.

TFESI provides a clinical improvement in the treatment of radiculopathy and neurogenic claudication caused by LSS in six months after the procedure. ${ }^{[21,22]} \mathrm{A}$ few studies, which include TFESI procedures and longer than six months of follow-up time performed in the literature. ${ }^{[23,24]}$ We evaluate and follow-up our patients at one year for determined improvement of pain and clinical status in the present study.

The level of LSS, which causes complaints (low back and bilateral leg pain), is determined with TFESI on multilevel LSS. ${ }^{[25]}$ Seven patients who determined at one year after TFESI procedure and who have worse ODI classification or 
high VAS were treated surgically. The level of surgery was pointed by TFESI and performed. TFESI procedure performs for the diagnostic approach.

TFESI procedure is more effective than other injection procedures (interlaminar and caudal) because of higher steroid density in the dorsal root ganglion and the clinical improvement of TFESI is higher. ${ }^{[26-28]}$

Extraepidural injection method is used with a TFESI procedure in our study. This method has been found to have better clinical improvement with less pain during the procedure than intraepidural injection. ${ }^{[29]}$

The chronic low back pain or radiculopathy that causes leg pain due to fibrosis or necrosis in the epidural area was determined by several studies in the literature. ${ }^{[15,30]}$ Oncu et al. investigated in 2014 the effects of lumbar epidural steroid injection in patients with radiculopathy and they reported that lumbar epidural corticosteroid injections were effective in patients with radiculopathy during the first three months after treatment. ${ }^{[31]}$ We comprehended that the complaints of four patients whose VAS results were not changed in the second-week evaluation after the procedure was longer than six months (chronic) in the present study. We found that this result was consistent with the studies in the literature. ${ }^{[24]}$

The patients who have minor or moderate stenosis are generally treated conservatively by medical or physical therapy. The surgical treatment is not preferred, and TFESI has a low rate due to the small case number of minor or moderate stenosis. The limitation of our present study is small case number of minor or moderate stenosis.

\section{Conclusion}

TFESI procedure is an effective non-surgical treatment for lumbar disc herniation, and it is commonly followed-up for six months. This procedure is rarely performed for LSS than disc herniation. We evaluated TFESI procedures for treatment and surgical indication of LSS. Our following of the patients, longer than six months, suggests that TFESI is safe procedure for non-surgical treatment of LSS and this procedure preferred support to an indication of surgical treatment of level of the LSS.

\section{Disclosures}

Ethics Committee Approval: Ethical approval was obtained from the Ethics Committee of İstanbul Medipol University. Approval No:1115/11122019.

Peer-review: Externally peer-reviewed.

Conflict of Interest: None declared.

Authorship Contributions: Concept - I.Y., O.K., M.A., H.C.; Design - I.Y., O.K., M.A.; Supervision - H.C., Y.A.; Materials - I.Y., M.A., H.C.;
Data collection \&/or processing - I.Y., M.A., H.C.; Analysis and/or interpretation - I.Y., O.K., H.C., Y.A.; Literature search - I.Y., O.K., H.C., Y.A.; Writing - I.Y., M.A., H.C.; Critical review - I.Y., H.C., Y.A.

\section{References}

1. Jenis LG, An HS. Spine update. Lumbar foraminal stenosis. Spine (Phila Pa 1976) 2000;25:389-94. [CrossRef]

2. Kunogi J, Hasue M. Diagnosis and operative treatment of intraforaminal and extraforaminal nerve root compression. Spine (Phila Pa 1976) 1991;16:1312-20. [CrossRef]

3. Porter RW, Hibbert C, Evans C. The natural history of root entrapment syndrome. Spine (Phila Pa 1976) 1984;9:418-21. [CrossRef]

4. Schizas C, Theumann N, Burn A, Tansey R, Wardlaw D, Smith FW, et al. Qualitative grading of severity of lumbar spinal stenosis based on the morphology of the dural sac on magnetic resonance images. Spine (Phila Pa 1976) 2010;35:1919-24. [CrossRef]

5. Manchikanti L, Cash KA, McManus CD, Pampati V, Fellows B. Results of 2-year follow-up of a randomized, double-blind, controlled trial of fluoroscopic caudal epidural injections in central spinal stenosis. Pain Physician 2012;15:371-84.

6. Young IA, Hyman GS, Packia-Raj LN, Cole AJ. The use of lumbar epidural/transforaminal steroids for managing spinal disease. J Am Acad Orthop Surg 2007;15:228-38. [CrossRef]

7. Harrast MA. Epidural steroid injections for lumbar spinal stenosis. Curr Rev Musculoskelet Med 2008;1:32-8. [CrossRef]

8. Buenaventura RM, Datta S, Abdi S, Smith HS. Systematic review of therapeutic lumbar transforaminal epidural steroid injections. Pain Physician 2009;12:233-51.

9. Epidural Steroid and Facet Injections for Spinal Pain. UnitedHealthcare $^{\circledast}$ Commercial Medical Policy. Available at: https:// www.uhcprovider.com/content/dam/provider/docs/public/ policies/comm-medical-drug/epidural-steroid-facet-injectionsspinal-pain.pdf. Accessed Jul 14, 2020.

10. Park Y, Lee WY, Ahn JK, Nam HS, Lee KH. Percutaneous Adhesiolysis Versus Transforaminal Epidural Steroid Injection for the Treatment of Chronic Radicular Pain Caused by Lumbar Foraminal Spinal Stenosis: A Retrospective Comparative Study. Ann Rehabil Med 2015;39:941-9. [CrossRef]

11. Chang MC, Lee DG. Outcome of Transforaminal Epidural Steroid Injection According to the Severity of Lumbar Foraminal Spinal Stenosis. Pain Physician 2018;21:67-72. [CrossRef]

12. Farooque M, Salzman MM, Ye Z. Effectiveness of Bilateral Transforaminal Epidural Steroid Injections in Degenerative Lumbar Spinal Stenosis Patients With Neurogenic Claudication: A Case Series. PM R 2017;9:26-31. [CrossRef]

13. Kim HJ, Yeom JS, Lee JW, Chang BS, Lee CK, Lee GW, et al. The influence of pain sensitivity on the treatment outcome of transforaminal epidural steroid injection in patients with lumbar spinal stenosis. Pain Pract 2014;14:405-12. [CrossRef]

14. Davis N, Hourigan P, Clarke A. Transforaminal epidural steroid injection in lumbar spinal stenosis: an observational study with 
two-year follow-up. Br J Neurosurg 2017;31:205-8. [CrossRef]

15. Olmarker $\mathrm{K}$, Holm S, Rosenqvist AL, Rydevik B. Experimental nerve root compression. A model of acute, graded compression of the porcine cauda equina and an analysis of neural and vascular anatomy. Spine (Phila Pa 1976) 1991;16:61-9. [CrossRef]

16. Jeong HS, Lee JW, Kim SH, Myung JS, Kim JH, Kang HS. Effectiveness of transforaminal epidural steroid injection by using a preganglionic approach: a prospective randomized controlled study. Radiology 2007;245:584-90. [CrossRef]

17. Lee JW, Kim SH, Choi JY, Yeom JS, Kim KJ, Chung SK, et al. Transforaminal epidural steroid injection for lumbosacral radiculopathy: preganglionic versus conventional approach. Korean J Radiol 2006;7:139-44. [CrossRef]

18. Onda A, Yabuki S, Kikuchi S, Satoh K, Myers RR. Effects of lidocaine on blood flow and endoneurial fluid pressure in a rat model of herniated nucleus pulposus. Spine (Phila Pa 1976) 2001;26:218692. [CrossRef]

19. Vad VB, Bhat AL, Lutz GE, Cammisa F. Transforaminal epidural steroid injections in lumbosacral radiculopathy: a prospective randomized study. Spine (Phila Pa 1976) 2002;27:11-6. [CrossRef]

20. Viton JM, Peretti-Viton P, Rubino T, Delarque A, Salamon N. Shortterm assessment of periradicular corticosteroid injections in lumbar radiculopathy associated with disc pathology. Neuroradiology 1998;40:59-62. [CrossRef]

21. North American Spine Society. Evidence-Based Clinical Guidelines for Multidisciplinary Spine Care: Diagnosis and Treatment of Lumbar Disc Herniation with Radiculopathy, 2012. Available at: https://www.spine.org/Portals/0/assets/downloads/ResearchClinicalCare/Guidelines/LumbarDiscHerniation.pdf. Accessed Jul $14,2020$.

22. North American Spine Society. Evidence-Based Clinical Guidelines for Multidisciplinary Spine Care: Diagnosis and Treatment of Degenerative Lumbar Spinal Stenosis, 2011. Available at: https://
www.spine.org/Portals/0/assets/downloads/ResearchClinicalCare/Guidelines/LumbarStenosis.pdf. Accessed Jul 14, 2020.

23. Cyteval C, Fescquet N, Thomas E, Decoux E, Blotman F, Taourel P. Predictive factors of efficacy of periradicular corticosteroid injections for lumbar radiculopathy. AJNR Am J Neuroradiol 2006;27:978-82.

24. Lutz GE, Vad VB, Wisneski RJ. Fluoroscopic transforaminal lumbar epidural steroids: an outcome study. Arch Phys Med Rehabil 1998;79:1362-6. [CrossRef]

25. Slosar PJ Jr, White AH, Wetzel FT. Controversy. The use of selective nerve root blocks: diagnostic, therapeutic, or placebo?. Spine (Phila Pa 1976) 1998;23:2253-6. [CrossRef]

26. Rho ME, Tang CT. The efficacy of lumbar epidural steroid injections: transforaminal, interlaminar, and caudal approaches. Phys Med Rehabil Clin N Am 2011;22:139-48. [CrossRef]

27. Roberts ST, Willick SE, Rho ME, Rittenberg JD. Efficacy of lumbosacral transforaminal epidural steroid injections: a systematic review. PM R 2009;1:657-68. [CrossRef]

28. Abdi S, Datta S, Trescot AM, Schultz DM, Adlaka R, Atluri SL, et al. Epidural steroids in the management of chronic spinal pain: a systematic review. Pain Physician 2007;10:185-212.

29. Lee JW, Kim SH, Lee IS, Choi JA, Choi JY, Hong SH, et al. Therapeutic effect and outcome predictors of sciatica treated using transforaminal epidural steroid injection. AJR Am J Roentgenol 2006;187:1427-31. [CrossRef]

30. Delamarter RB, Bohlman HH, Dodge LD, Biro C. Experimental lumbar spinal stenosis. Analysis of the cortical evoked potentials, microvasculature, and histopathology. J Bone Joint Surg Am 1990;72:110-20. [CrossRef]

31. Oncu J, Iliser R, Celebi G, Kuran B, Durlanık G. Efficacy of lumbar epidural corticosteroid injections on clinical status of the patients with radiculopathy. Med Bull Sisli Etfal Hosp 2014;48:34-8. [CrossRef] 